(c) The Author(s), 2021. Published by Cambridge University Press. This is an Open Access article, distributed under the terms of the Creative Commons Attribution licence (http://creativecommons.org/licenses/by/4.0/), which permits unrestricted re-use, distribution, and reproduction in any medium, provided the original work is properly cited. doi:10.1017/S147474642000072X

\title{
Religion, Populism, and the Politics of the Sustainable Development Goals
}

\author{
Jörg Haustein* and Emma Tomalin** \\ *University of Cambridge, UK \\ E-mail: jh2227@cam.ac.uk \\ **University of Leeds, UK \\ E-mail: e.tomalin@leeds.ac.uk
}

This article examines the Sustainable Development Goals (SDG) framework as a political project in tension with its universal and multilateral aspirations to serve as a counterbalance to narrow populist visions increasingly dominating global politics. Building upon Laclau and Mouffe's theory of populism and their notion of 'radical democracy', we conceptualise the SDGs as a struggle for hegemony and in competition with other styles of politics, over what counts as 'development'. This hegemonial struggle plays out in the attempts to form political constituencies behind developmental slogans, and it is here that religious actors come to the fore, given their already established role in organising communities, expressing values and aspirations, and articulating visions of the future. Examining how the SDG process has engaged with faith actors in India and Ethiopia, as well as how the Indian and Ethiopian states have engaged with religion in defining development, we argue that a 'radical democracy' of sustainable development requires a more intentional effort at integrating religious actors in the implementation of the SDGs.

Keywords: Religion, populism, Sustainable Development Goals, Ethiopia, India.

\section{Introduction}

The UN Sustainable Development Goals (SDGs) presents the foremost framework for development policy worldwide. The SDGs consist of seventeen goals and 169 targets for planning and measuring development, continuing and ambitiously extending the previous framework of the eight Millennium Development Goals (MDGs). Adopted in 2015 by all 193 member states of the UN, the SDG framework appears to serve as a counterpoint to the anti-globalisation and nationalist shift to populist politics that has been gaining traction in recent years. Although the framework was negotiated and set in New York City at the UN headquarters, the SDGs involved a more wide-reaching consultation process than the MDGs, engaging with states, the private sector, and civil society in setting the goals, targets and indicators (Tomalin et al., 2019). Moreover, the notion of sustainability alongside this multi-stakeholder consultation appeared to signal the intention to base this new development framework in local cultural contexts and their respective values. In many countries, this would mean drawing upon religions as a venue for projecting futures, articulating values, and organising communities. This is not an entirely new approach. In fact, the relevance of religious identities and actors for global, national and local development discourses has risen in significance over the past decades. At the level of 
global development policy and practice, faith-based organisations (FBOs) are more likely than before to receive donor funding for development and humanitarian work, and evidence for the positive role that faith actors can play in social welfare is as likely to be stressed as the challenges such engagement can bring (Tomalin, 2013, 2015).

The consultative framework of the SDGs and its potential for including faith actors in its vision of sustainability prompted us to conduct exploratory research in Ethiopia, India, and the UK, aimed at finding out, firstly, whether the civil society consultation process was as successful as claimed with regard to the inclusion of faith actors and their perspectives, and secondly, how religious organisations are engaging in the early implementation phase of the SDGs. In the context of a research networking project funded by the UK Arts and Humanities Research Council, titled 'Keeping Faith in 2030: religions and the sustainable development goals', we conducted three participatory workshops in India, Ethiopia, and the UK from 2017 to 2019, and obtained ten key informant interviews. The workshops gathered representatives from the most relevant national and international FBOs and involved various activities to discuss how they were involved in the consultation and negotiation process to set the SDGs as well as how they were interpreting, adopting and implementing them in their work with local communities. ${ }^{1}$ Each followed the same format of a small group discussions of set questions, so that comparisons could be made. These were recorded, and detailed notes taken, and our findings were published in a series of reports and articles (see esp. Haustein and Tomalin, 2019; Tomalin and Haustein, 2020; Tomalin et al., 2019, see also https://religions-and-development.leeds.ac.uk/researchnetwork).

The findings from this preliminary research indicate that the SDGs are far from forming an alternative, internationalist development platform to counter populist agendas, at least as far as the important dimension of religion is concerned. Their reach among FBOs was extraordinarily low, with few involved in the global consultations. Where FBOs did engage with the SDGs, this was mostly prompted by top-down reporting structures rather than the usefulness of the framework. Furthermore, while some interlocutors saw potential in the SDGs for holding their governments to account, the early implementation reports in the Voluntary National Reviews (VNRs) of India and Ethiopia suggest the opposite: governments are subverting and rescripting the SDG agenda to suit their populist politics.

While these initial findings need to be deepened in further studies, they point to an emerging hiatus between the aspiration of the SDGs to form a multi-lateral development effort and the significant state capture the SDG process allows. This calls into question the juxtaposition between the internationalist framework of the SDGs and the rise of local or national populisms. Can the SDG process and its multi-stakeholder framework be positioned as a suitable antidote to the rise of populism? Or is the implementation of the SDGs threatened if not thwarted by populist governments? Are both processes even in competition, or do they cater to different constituents and political echo chambers? How do religions participate in each, and how have religious actors been addressed by the SDG process and populists in India and Ethiopia? And finally, is it justified to see them juxtaposed as inherently different political processes, with the SDGs following a liberal, inclusive ethos to development, and populism an instrumentalist and potentially exclusive one?

These questions prompt us to rethink the relationship between international and national development policy in order to understand the challenges the SDGs are facing in this early implementation period, especially in the mobilisation of local facilitators such as 
FBOs in restrictive national environments. We begin by drawing upon the theory of populism offered by Laclau and Mouffe (1987), which offers a way of breaking down the problematic binary between 'progressive' multi-lateral politics and 'retrograde' particularistic populist politics, instead viewing populist strategies as endemic to politics as a whole. Next we apply this framework to the SDGs. While others have drawn attention to the politics of the SDG framework for masking a Northern neo-liberal agenda under the guise of universalism (e.g. Fukuda-Parr and McNeill, 2019; Gabay and Ilcan, 2017), our engagement with Laclau and Mouffe (1987) offers an original contribution to debates in this area in reframing the SDG process as a form of development popularism in itself that stands in competition rather than in contrast with nationalist politics. We will also show that religions operate in the same terrain of constructing 'the people' of development, making them a vital resource within this competition. In the remaining two sections, we present our findings from India and Ethiopia from this Laclauian perspective to illustrate how the aspirations of the SDG platform are being side-lined by national governments and fail to resonate at the grassroots level, but also how religious actors offer a resource to overcome these challenges. We conclude the article with comparative reflections to the questions set out above.

\section{Hegemony and empty signifiers: on the rationality of populism}

In the introduction to this themed section, the editors note that Laclau and Mouffe's notion of populism has an unexplored potential for the policy world (1987). We agree, because Laclau and Mouffe open up new analytical space for how policy frameworks succeed and fail. Rejecting the problematic distinction between populist and non-populist discourses, Laclau and Mouffe focus on how political majorities are organised around a perceived foundational identity. For policy frameworks, such as the SDGs, the question of their success does not depend on the rationality or persuasiveness of their content alone, but on how they manage to mobilise a plurality of actors under a common demand or signifier. This requires moving beyond satisfying elites (which is just as likely to be a marker of liberal political frameworks as those termed 'populist') and instead to enable a broad hegemonial struggle - a 'radical democracy' - as to what symbolises and encapsulates this common demand.

Laclau and Mouffe's understanding of society is captured in their theory of discourse and rests upon the rejection of any ontological ground beyond the 'play of differences' (Laclau, 2005: 69). This leaves no privileged, a priori vantage point for political analysis, like class, (social) function, or material conditions. All such identities and distinctions are seen to arise within the play of difference itself, as indeed is any signification, as de Saussure has shown (Laclau, 1994: 168). This interdependence of all identity articulations leaves us with the problem of an open-ended system: how can political discourses assert meaning and values if everything is relative? Laclau and Mouffe conclude that a preliminary closure or boundary is necessary, because without a 'fictitious fixing of meaning there would be no meaning at all' (Laclau, 1996: 205). Therefore, social identities like family, ethnicity, or nation are only possible by introducing arbitrary boundaries. Politics becomes the necessary ground for the emergence of social identities.

Within a system of relational differences, such boundaries or closures cannot be represented by another difference, but only as an antagonistic outside, as 'pure negativity' (Laclau, 1994: 170). This is made possible by subverting the system of differential 
relations, by 'privileging the dimension of equivalence to the point that its differential nature is almost entirely obliterated' (Laclau, 1994: 171). Put in simple political terms: 'our' differences pale in comparison to 'those' people who threaten our very existence as a social group.

This constitutive equivalence is represented within any discourse by what Laclau and Mouffe called a 'floating signifier' (Laclau and Mouffe, 1987) or 'empty signifier' (Laclau, 1994). This denotes an element of the equivalential chain, which has been stripped of its referent to stand for the equivalence itself. Populist movements therefore arise when differential demands are absorbed into a chain of equivalences under a name that originated from a particular demand but came to signify the movement itself. Examples for this abound from 'liberté, égalité, fraternité' to 'make America great again.' Which signifier from the equivalential chain takes on this role is the result of a 'particular conjuncture' and produces a 'hegemonic relationship' (Laclau, 1994: 175), because constructing an empty signifier is not 'a conceptual operation of finding an abstract common feature' but 'a performative operation constituting the chain as such' (Laclau, 2005: 97). The forceful articulation of the empty signifier produces the perceived equivalence - it becomes tangible through the shared slogan.

It is easy to see that this act of 'constructing the "people" (Laclau, 2005: 66) is not a proprietary feature of populism but points to the structure of politics as a whole. This is why Laclau bemoans the intellectual vacuity of the category of populism and suspects that behind its dismissal or downgrading is the 'denigration of the masses' (Laclau, 2005: 63). Populism is no longer understood as a 'fixed constellation but a series of discursive resources which can be put to very different uses' (Laclau, 2005: 176). Moreover, the 'minimal unit of analysis' is no longer the group, but the 'socio-political demand' (Laclau, 2005: 224), so that the question of analysing 'populism' is not how and why 'populist' politicians lead 'the people' astray, but how demands are being mobilised and drawn together to 'construct "a people".' This allows for a more fine-grained analysis of political mobilisation than the juxtaposition of populism with liberal democracy. Laclau and Mouffe develop from this the project of 'radical democracy': rather than narrowing the field of politics in the name of a universal (as in a Leninist approach), the new left needs to attain hegemony by renouncing the 'discourse of the universal' (Laclau and Mouffe, 1987: 192) and aim for a diversification of demands under a maximally broadened chain of equivalences.

\section{Populism, the SDGs, and religion: constructing 'the people' of development}

The universalism of the SDGs has been juxtaposed against an inward-looking mood that increasingly influences global politics (Glennie, 2019; Marschall and Klingebiel 2019). Our analysis, however, leads to a different perspective. From the vantage point of Laclau and Mouffe, it is important to suspend the value-laden juxtaposition of universalism versus nationalism in favour of understanding them as engaged over one and the same hegemonial struggle over 'development': How do both the SDG framework and nationalist politicians seek to mobilise social demands in the interest of collecting constituencies? This draws attention to surprising parallels. For instance, the phrase 'leave no one behind' was not only used as the underpinning motto of the SDGs, part of a push for more inclusiveness in development thinking after the MDGs (OECD, 2018; Kharas et al., 2019), but also as a powerful election slogan by Narendra Modi, the Hindu nationalist president of India, even before the adoption of it by the SDGs (Malhotra, 2020). Wraight provides a 
critique of the notion of the 'left-behind' as 'an inherently value-laden term' thereby lending itself to blaming perpetrators or 'valorising communities as "victims"' $(2018: 7,9)$. This, we argue, highlights that the phrase is a construction employed by both the SDGs and populist governments, where each define a population that is to be 'caught' up according to their own normative standard. This is not to argue that Modi and the SDGs are pursuing a similar programme or agree on what counts as progress and development. Modi's construction of the people who are 'left behind' does not include religious and ethnic minorities outside the Hindu populous and represents a specific hegemonial occupation of the 'left behind' (i.e. the repressed, 'backward' Hindu). However, the shared use of this slogan does point to the parallelism of their hegemonic operation in constructing 'the people' of development. A number of differential demands for better nutrition, water, education, gender equality, infrastructure, etc. are subsumed under the empty signifier of the 'left behind' which constitutes the discourse of global development and nationalistic progress rhetoric alike. In this sense, both the universalism of the SDGs and the nationalism of 'populist' government are engaged in a hegemonic struggle: who speaks for the 'left behind,' how will they be 'caught up' and to what landmarks of progress? In a political sense, the question of the success and indeed sustainability of the SDGs, therefore, does not hinge on an abstract global competition between liberal universalism and national populism, but on how effectively national governments and the UN SDG process assert their hegemony over defining the equivalential chain of deprivation and development in their chosen settings. Therefore, in this Laclauian perspective, 'populist' politicians such as Modi are not the antagonistic outside of development discourse, but its direct competitors in mobilising and uniting the same constituents and their ambitions.

Brown, writing more generally on the concept of 'sustainability' in politics, has similarly argued that the notion of sustainable development has served the 'existing powers' in preventing a threat to their dominant position by capturing 'sustainability' as an 'empty signifier' and denying it's radical potential (2016: 130). In order to correct these failures, Brown looks to civil society as the only place where 'new articulations of sustainability can [...] take shape' (Brown 2016: 130). This would entail to draw in diverse constituencies and their different demands for 'a more authentic sustainability politics' (Brown, 2016: 128) and utilise the 'empty signifier' of 'sustainability' as a basis for a radical democracy against the current system that fails to articulate a collective future (Brown, 2016: 128-9). While we agree with Brown in general, we would caution against valorising the notion of civil society as a golden ticket to greater inclusion or democracy. Rather, we side with Munck (2002), who understood 'global civil society' as a 'floating signifier' following Laclau. This means to demarcate the notion of global civil society as part of a struggle for hegemony and a possible site for 'radical democracy.' The SDGs have become part of this hegemonic struggle, claiming to speak with and for civil society in collecting and articulating global development aspirations. The question then becomes how successful this claim to 'the people of development' has been, especially in competition with national governments, and whether the SDGs offer a platform that can be broadened in the direction of 'radical democracy' as a way to circumvent narrow national and global agendas. We recognise that the SDG framework is not lacking in universal ambition, which might indeed make it seem suitable to broadening the equivalential chains of 'sustainable development' in a trajectory of 'radical democracy'. But just as 'radical democracy' is not a rhetorical ambition but a hegemonic process, the 
success of the SDG framework will ultimately depend on the extent to which it manages to connect with various vectors of civil society in order to mobilise and unite local development demands in a global movement, instead of relying on narrow national planning frameworks and their political purposes. This is where religions come to the fore as an important factor.

Religions are understood here in the Laclauian sense not as universal ontological entities but as systems that produce (often historically sedimented) discursive closures via equivalential chains (Bergunder, 2014). This has a number of implications. Firstly, what is included in this equivalential chain and what forms its 'floating' or 'empty signifier' may differ from context to context. This means to study in detail what sort of equivalences religious identities and actors stand for and what antagonistic closures they demarcate - or, in other words, who or what is seen to be a legitimate (even if contested) part of a particular religious discourse and what is framed as inimical or entirely irrelevant to its inner logic. This may or may not include political statements, the provision of welfare, dietary regimes, environmental guidance and so on, depending on the particular historical constellation of a religious discourse. Secondly, if religions are reconceptualised as discursive articulations within the same political space of competing 'empty signifiers', the question is how their demands can be included in a 'radical democracy' of development. While secularist thought no longer completely dominates the social and political sciences, as well as global development policy and practice, where multi-lateral frameworks such as the SDGs do engage with religion they do so in a narrow and instrumentalist way that picks and chooses which type of religion and faith actors to partner with. A Laclauian-inspired approach to religion and the SDGs, seeking to effect a radical democracy, needs to move beyond such an instrumentalist approach and instead link up with the diverse ways that faith and faith actors inspire and frustrate the aims of the SDGs. Finally, rather than the premise of discursive closure resting upon inclusion in a moral and spiritual community with shared religious beliefs, Laclau's approach lends itself to thinking about religious identity as a fluctuating political rather than fixed social category where one's belonging in a community is a dynamic of constantly actualised inclusion/exclusion, as in India.

Thus, religious communities operate in the same discursive terrain as the SDGs, mobilising social demands and development ambitions under empty signifiers such as 'salvation,' 'dīn,', or 'dharma.' Therefore, the question for the remainder of this article is whether and how the SDG agenda can be broadened to include religious actors in India and Ethiopia in a 'radical democracy' of development by broadening the empty signifier of 'sustainable development' to include its counterparts within religious discourse. So far, a perspective of instrumentalism prevails, where religious communities are recruited to help deliver progress in the name of the SDGs, but had next to no input in shaping the goals and their targets (Tomalin et al., 2019: 109-110). In addition, beyond collaboration in securing basic needs, religious actors are often seen in global development discourse as a hindrance to achieving progress. This is what makes a local perspective interesting: how do religious actors view and engage with the SDG goals and targets, and do they see the same discrepancies as global development actors?

We will now discuss these challenges with regard to India and Ethiopia, drawing upon the above-mentioned workshops in both countries. This will be guided by the following questions: Firstly, how does the state implement the SDG framework and what does this mean for the local hegemony of the UN's SDG process? Secondly, how does the 
nexus of politics, development, and religions play out in each country? And finally, how do faith actors engage with the SDG framework and what might this mean for the local potential of the SDG process?

\section{Religion, populism, and the politics of the SDGs in India}

The Government of India has engaged actively in the SDG process, submitting Voluntary National Reviews (VNR) in 2017 and 2020 (NITI Aayog, 2017, 2020). The 2017 VNR claimed that 'the country's war against poverty has become fundamentally focused on social inclusion and empowerment of the poor', clearly aligning with the SDG slogan to 'leave no-one behind' (NITI Aayog, 2017: v). The malleability of the empty signifier 'leave no-one behind' has enabled the Indian government to domesticate the SDG agenda to suit their populist politics, asserting local hegemony over the SDG process. From the outset of the SDG process, the government stressed that the 'country's national development goals are mirrored in the SDGs [... ] The memorable phrase Sabka Saath Sabka Vikas, translated as "Collective Effort, Inclusive Development" ... forms the cornerstone of India's national development agenda' (NITI Aayog, 2017: v). Given that the Indian government is driven by a Hindu nationalist agenda - which can be characterised as a form of 'religious populism' (Zuquete, 2017) - its construction of 'inclusive development' is at odds with the SDG notion of 'leave no-one behind'. Brubaker argues that populist movements, figures, and regimes claim 'to speak in the name of "the people" and against various "elites"' (2017: 359). For Hindu Nationalists, the people are the Hindus and the enemy - or the antagonist outsider, to reference Laclau - are the 'English-speaking, Westernized uprooted - elites' (Jaffrelot and Tillin, 2017: 5). In this version of populism, we find Muslims, and indeed other religious minorities, as enemies outside the Hindu cultural community, outside the equivalential chain of the 'left behind'. This has given rise to cultural and socio-economic marginalisation of Muslims in particular (Sachar, 2006; Shariff, 2016). Those who have drawn attention to Muslim disadvantage in India, particularly since the publication of the 2006 Sachar Committee Report, are involved in a tussle to lengthen the chain of the 'left behind'. Empty signifiers such as Hindurastra, Hindu nation, serve nationalism in pulling together the demands of different groups of citizens who have been convinced that they have suffered at the hands of the secular liberal elite and their preference for serving Muslim needs.

Kazmin tells us that 'during his first prime ministerial campaign in 2014, Modi played down the Hindutva [Hindu nationalist] aspect of his political persona' (Kazmin, 2019). However, according to Vaishnav 'since clinching a historic re-election [...] the BJP appears to have prioritized majoritarianism over economic renewal' (Vaishnav, 2020). This has included the criminalisation of the Muslim instant triple talaq or instant divorce in July 2019 (Woodyatt and Pokharel, 2019) - viewed by many Muslims as an example of the state interfering in religion, the revoking of the autonomy of Muslim majority Indian-administered Kashmir in August 2019 (Hussain, 2019), the decision of the supreme court in November 2019 to permit the rebuilding of a Hindu temple in Ayodhya on the disputed site where the Babri Mosque was pulled down by Hindu militants in 1992 (Ellis-Petersen, 2019), the passing in December 2020 of the Citizen Amendment Bill which allows illegal migrant members of all religions apart from Islam to have the right to Indian citizenship (Kuchay, 2019), as well as increasing 'cow vigilantism', or lynchings of cattle traders (HRW, 2019). This is against the backdrop of a 
shrinking civil society space, where the state increasingly stands in the way of civil society organisations (CSOs) mobilising and advocating on behalf of the marginalised and minorities. CSOs/NGOs that are faith-based face additional challenges since the Modi government is particularly sensitive to those that are viewed as engaging in conversion activities. Given this political context, it is striking that, on the one hand, the 2020 SDG VNR articulates an increased commitment to 'leave no-one behind' and to localise the SDGs via the village level gram panchayat system of local governance and the consultation of over 1000 CSOs in the production of the report (NITI Aayog, 2020), but, on the other hand, makes no reference to religion as an identity marker or as a source of continuing social, political and economic inequality, nor the role of faith actors in representing marginalised communities or localising the SDGs.

When we held our 'Keeping Faith in 2030' workshop in New Delhi, India, in December 2017, we learnt that most of the participants - which included representatives of Christian, Buddhist, Muslim and Hindu national and international faith based organisations - had been unaware of the local consultation meetings to decide the SDGs, although some had been more recently involved the consultation to set the national level indicators for the SDGs (Tomalin et al., 2017). We heard that national and local faith leaders had not been involved in these consultations and where faithbased organisations (e.g. World Vision) did take part they did so as civil society groups rather than as FBOs. Those FBOs that were involved in the SDG consultations appeared to be those who were already 'at the table' and could comfortably converse in the international development lexicon (Tomalin, 2019). While most participants told us that the SDGs had not changed the way they worked, the SDG framework was shaping how they branded their activities and articulated them to the outside world. This did not mean that the SDG framework was benignly irrelevant in its impact. The majority of those present at the workshop represented minority faith traditions in India, namely Christianity, Buddhism and Islam, and for them the SDG framework had a very real impact on their work in enabling them to link to networks and mechanisms outside the parochialisms and populisms that perpetuated their marginalisation and enabled them to build solidarity with others transnationally.

When it came to discussion of the relationship between religion and the SDGs, two approaches were apparent. Firstly, most participants stressed that the SDGs were secular or universal goals (i.e. not relating to the particularistic views of certain religions) and they did not use religious language to reference or contextualise the SDGs. When they publicly spoke about themselves as faith-based organisations, they did so as representatives of the interests of marginalised groups that shared a faith tradition rather than as a moral community that has a privileged perspective grounded in religious teachings on how to achieve change. This emphasis on FBOs as social rather than moral entities is, we suggest, a reaction to rising Hindu nationalism that makes it dangerous for minority faiths to claim public moral space. However, it also reveals an important disconnect with the global discourse driving the 'turn to religion' by international development policy and practice over the past couple of decades that addresses them as moral communities. Secondly, within local faith communities (and away from public view) some FBOs were using religious language to articulate the SDGs to their constituencies, particularly against religious views being used to justify attitudes and behaviours (such as gender inequality) that would compromise SDG success (Tomalin and Haustein, 2020). 


\section{Religion, populism, and the politics of the SDGs in Ethiopia}

Development targets and achievements are at the forefront of Ethiopia's political discourse, pursuant of a Chinese model of state-led economic growth. With high GDP growth rates in the last fifteen years, rising exports, and foreign investment in infrastructure, Ethiopia has the stated aim of becoming a middle-income country by 2025 . Ethiopia has engaged actively with the SDG process, building on its significant successes in pursuing the preceding MDGs. It was one of fifty countries worldwide to provide data in preparation of the SDG agenda, joined forces with nine other African countries in preparing the 'Common African Position,' and submitted a Voluntary National Review (VNR) in 2017 (FDRE, 2017).

At the same time, it is very clear that this engagement is mainly for the benefit of foreign diplomacy because within the country the SDGs have not been adopted as a development framework. Ethiopia pursues its own five-year development plans, the socalled Growth and Transformation Plans (GTPs), with the still current GTP II adopted in 2015 just after the country signed on to the SDG. The GTP II pursues a much narrower vision of development, focused almost entirely on economic growth, and the 2017 VNR has defended this approach against the SDG framework. More welfare-oriented goals, such as gender equality, are slotted into economic targets, and the performance indicators in the VNR line up with the GTP II rather than the SDG targets (FDRE, 2017: 8-9, 47-50). The VNR sets out this prioritisation in unmistakable terms:

Thus, in the context of Ethiopia, implementing the current Second Growth and Transformation Plan (GTP II) and its successors means implementing the SDGs. There is and will be one national development plan in which the SDGs are mainstreamed (FDRE, 2017: 41).

This nationalisation of the SDGs was in line with the top-down mode of development planning and the strict controls on CSOs that were imposed until recently. Most significantly, the 2009 Proclamation on Charities and Societies (PCS) had established a problematic dividing line between advocacy and development, mainly in order to cut off foreign assistance to Ethiopian NGOs working in the area of human rights (Woldegiorgis, 2009). For religious actors, this entailed a strict separation between religious (advocacy) and charitable (development) activities, which was not practicable when addressing developmental issues connected to religious discourses, such as FGM/C. Moreover, the PCS also created the Charities and Societies Agency (CSA), which was staffed by the government and given oversight of the entire CSO sector with substantial rights to intervene.

When Abiy Ahmed came to power in 2018, the political space for civil society actors opened up considerably. The new 2019 Civil Society Proclamation (CSP) lifted advocacy funding restrictions, removed many obstacles for the involvement of foreign actors, and placed the CSA on a more representative, democratic footing. Some limits remain, but the positive impact of the CSP on the CSO sector is already visible (Staberock and Christopoulos, 2019). At the same time, development has become an even more integral part of Abiy's political platform. Seeking to transcend the divide-and-conquer strategy of the ethno-regional federalism installed and maintained by his predecessors, Abiy has dissolved the coalition of ethnic parties governing the country and formed a new national party from most of its former constituents, which will be the incumbent in the upcoming elections. The name of the new party is 'Prosperity Party,' its stated motto is 'turning a 
prosperous Ethiopia into reality, ' and its indicators of prosperity are similarly wide-ranging as the SDGs - from basic needs and healthcare to quality education, peace, and environmental care (Prosperity Party, 2019: 5).

Moreover, Abiy has brought religion to the fore in his political rhetoric (Feyissa and Haustein, forthcoming). As a Pentecostal with a multi-religious background, he has departed sharply from the symbolic secularism of the state under his predecessors (one of whom was a Pentecostal as well, see Haustein, 2013), and engages religion in multiple settings: from adding the phrase 'God bless Ethiopia' to all his political speeches to lecturing religious leaders and brokering peace within religious communities. Abiy's political career began with inter-religious peace-building efforts and in his PhD thesis he argued that religions are an important source of social capital in the country (Feyissa and Haustein, forthcoming). It is no wonder then that he is seeking to employ religious communities as a resource for his vision of Ethiopian unity, progress and development. In a particularly instructive speech, given at a large gathering of a Pentecostal youth organisation, Abiy linked his prosperity agenda to his faith by declaring to his rapt audience that by God's power, Ethiopia would prosper to become one of the top five African economies by 2030.

In contrast with Abiy's religious populism, Ethiopia faces enormous political struggles at the moment, from violent ethnic riots, with millions of internally displaced citizens, to unresolved conflicts over Abiy's political reforms and the indefinitely postponed national election (justified with COVID-19). Armed conflict with Oromo separatist movements in the west and with the remnants of the Tigray regional government in the north have further highlighted the precariousness of Ethiopia's national unity, and the government has been returning to more coercive measures in the imprisonment of journalists and opposition figures. It thus remains to be seen whether Abiy's religio-political construction of 'the people of development' will prevail and through which political means. What is certain, however, is that the politicisation of development promises has only increased, risking a further marginalisation of the SDG framework in Ethiopian political discourse.

When we ran our workshop in Ethiopia in September 2018 with a representative selection of NGOs and FBOs (Haustein and Tomalin, 2018), we found that none of the assembled organisations had been involved in the SDG consulting process, and few had even heard about the SDGs, mostly through reporting structures of international NGOs/ FBOs (Haustein and Tomalin, 2018). An overwhelming majority stated that the SDGs would make little or no difference to their work, which was guided rather by their own programmatic priorities, their constituents' needs, and the demands of Ethiopia's centralised development planning. While the latter constraint may have eased a bit, it is difficult to argue that the political capture of the development sector has markedly reduced under Abiy. Furthermore, given the breadth and generality of the SDGs, participants struggled to see the benefits of this framework for their work, even as they acknowledged the general usefulness of international development co-ordination under this umbrella. The secularity of the SDGs and potential tensions between religious values and some targets were noted, but not seen as a substantial problem, because the FBOs present saw themselves as translators between global development aspirations and local cultures. They did note, however, that the SDG framework's lack of references to ethics and morality made them less suitable for translation into religious language. Here too, it would seem, that Abiy's religious mobilisation rhetoric had the upper hand. Overall, there was sustained interest in getting to know the SDGs as a global development framework, 
but given their generality and political marginalisation in Ethiopia, it was hard to see how religious actors and other local development organisations could be mobilised around this framework for a common global agenda for development.

\section{Discussion and conclusion}

In the conclusion to his Laclauian analysis of the semantics of sustainability, Brown noted:

Despite the many attempts to provide it a definition, sustainability remains an 'empty' term in practice, having no precise content. This lack of precision should certainly attract critique, particularly when it enables 'empty gestures' on the part of politicians and other key decisionmakers. The versatility that comes with sustainability's lack of fixed meaning has certainly enabled elites to present it in ways that suit their own agenda, as has clearly been the case with the 'sustainable development' approach. However, such critique should not blind us to the potential of sustainability to open new social and political opportunities (Brown, 2016: 130).

We agree with this hopeful note in principle as well as with Brown's warning that the current configuration of sustainability as 'sustainable development' fails to achieve this promise. This is not just because the vision of sustainability is too narrowly tied to global elites, as Brown seems to suggest, but also because the implementation framework has relied on nation state actors more than on local CSOs. Drawing upon our research on faith actors' engagement with the SDGs in Ethiopia and India, we argue that this failure of the SDG process to engage with local CSOs, sets national governments up against the UN framework, not in a competition between 'populism' and 'multi-lateralism', but in a mutual hegemonic struggle of who speaks on behalf of the 'left behind' or 'the people' of development. Both countries have astutely used the SDG process to define their own national agendas for development, which in both cases severely limits the equivalential chains the SDG framework has sought to build. Of course, Ethiopia and India are somewhat unique cases, since both are well-known as countries that are more resistant than others to perceived outside influences. So comparative research in other countries would have to show if similar dynamics are in play there as well. Given the similar process in the SDG implementation and reporting everywhere, we would suspect that this may well be the case, because in its over-reliance on nation state actors the UN agenda risks strong government capture of the process everywhere.

In order to circumvent this hegemonial struggle between the UN and national governments, the SDG framework needs to rely much more on CSOs including those that are faith-based. During the setting of the goals, this was an emphasis of the SDG process, even though our research would suggest that its reach was not as deep as proclaimed. In the current implementation the target setting and reporting structure appears to depend entirely on national policy, with no concerted efforts to integrate local civil society actors. This can have very uneven effects and fails to maximise the impact of the SDG framework. Our research in India, in particular, has shown that some civil society actors see a potential in the SDG platform for counter-balancing narrow national discourses, and this needs to be developed.

Furthermore, we see a potency in the mobilisation of religious actors for the SDGs, especially in contexts like India and Ethiopia, where religions are an integral part of nationalist mobilisation platforms. A closer integration of religious actors in an 
international sustainable development platform would certainly be a contribution to preventing their co-optation or marginalisation at the hand of national populists. This would require a more intentional effort than simply enlisting religious actors for the implementation of the SDGs. Instead, the chain of equivalences currently signified by 'sustainable development' would need to embrace a larger diversity of religious views about progress, development, and sustainability - a further emptying out of the 'empty signifier' in the interest of a wider mobilisation. This is not a call for 'religious adjustments' in the goals or targets, especially as our interlocutors in India and Ethiopia have embraced the SDGs as a multinational, religious neutral framework and have signalled less doctrinal conflict than global discourses about religion and development would suggest. What is needed instead is a stronger commitment to a radical democracy of sustainable development that can still signify a common cause and aspiration for a better future even when disagreements and differences in the values, trajectories, and measurements of development come to the fore between religious communities and the globalist, multilateral framework of the SDGs. Our workshops certainly suggested that religious actors are interested to buy into the SDG framework if it helps them transcend national limitations and allows them to play an intermediary role between international development discourse and the local culture of their respective religious communities.

\section{Acknowledgements}

The authors would like to thank the editors of this themed section for inviting our contribution and for their helpful comments and editorial feedback along the way. We are also grateful to the anonymous reviewers of this piece for their encouraging remarks and their suggestions for improving the clarity of our argument.

\section{Note}

1 The workshop reports available at https://religions-and-development.leeds.ac.uk/researchnetwork provide more details about the FBOs involved. A full list of participant organisations can be obtained from the authors.

\section{References}

Bergunder, M. (2014) 'What is religion? The unexplained subject matter of religious studies', Method and Theory in the Study of Religions, 26, 246-86.

Brown, T. (2016) 'Sustainability as empty signifier: its rise, fall, and radical potential', Antipode, 48, 1, 115-33. Brubaker, R. (2017) 'Why populism?', Theory and Society, 46(5): 357-85.

Ellis-Petersen, H. (2019) 'Ayodhya: India's top court gives Hindus site claimed by Muslims', The Guardian, https://www.theguardian.com/world/2019/nov/09/ayodhya-verdict-hindus-win-possession-of-sitedisputed-by-muslims [accessed 30.11.2020].

Federal Democratic Republic of Ethiopia (FDRE) (2017) The 2017 Voluntary National Reviews on SDGs of Ethiopia: Government Commitments, National Ownership and Performance Trends, Addis Ababa: National Planning Commission, https://sustainabledevelopment.un.org/content/documents/ 16437Ethiopia.pdf [accessed 30.11.2020].

Feyissa, D. and Haustein, J. (forthcoming) 'The strains of 'Pente' politics: evangelicals and the post-orthodox state in Ethiopia', in J.-N. Nicolas Bach (ed.), The Routledge Handbook on the Horn of Africa, London: Routledge. 
Fukuda-Parr, S. and McNeill, D. (2019) 'Knowledge and politics in setting and measuring the SDGs: introduction to special issue', Global Policy, 10, S1, 5-15.

Gabay, C. and Ilcan, S. (2017) 'Leaving no-one behind? The politics of destination in the 2030 sustainable development goals', Globalizations, 14, 3, 337-42.

Glennie, J. (2019) 'Countering populism', SDGs: Transforming Our World, London: UNA-UK, https://www. sustainablegoals.org.uk/countering-populism [accessed 30.11.2020].

Haustein, J. (2013) 'The new Prime Minister's faith: a look at Oneness Pentecostalism in Ethiopia', PentecoStudies, 12, 2, 183-204.

Haustein, J. and Tomalin, E. (2018) Workshop Report: Religions and Development in Ethiopia, Addis Ababa $20^{\text {th }}-21^{\text {st }}$ September, https://religions-and-development.leeds.ac.uk/wp-content/uploads/sites/10/ 2019/02/Workshop-Report-Ethiopia-Final-corr1.pdf [accessed 30.11.2020].

Haustein, J. and Tomalin, E. (2019) Keeping Faith in 2030: Religions and the Sustainable Development Goals: Findings and Recommendations, https://religions-and-development.leeds.ac.uk/wp-content/ uploads/sites/10/2019/02/Policy-Paper-for-web.pdf [accessed 30.11.2020].

HRW (2019) Violent Cow Protection in India. Vigilante Groups Attack Minorities, New York: Human Rights Watch, https://www.hrw.org/report/2019/02/18/violent-cow-protection-india/vigilante-groups-attackminorities [accessed 30.11.2020].

Hussain, M. (2019) 'India moves to strip Kashmir of autonomy, potentially setting up conflict in disputed territory', The Intercept, 5 August, https://theintercept.com/2019/08/05/india-kashmir-autonomystatus/ [accessed 30.11.2020].

Jaffrelot, C. and Tillin, L. (2017) 'Populism in India', in C. R. Kaltwasser, P. Taggart, P. O. Espejo and P. Ostiguy (ed.), The Oxford Handbook of Populism, Oxford: Oxford University Press, 179-94.

Kazmin, A. (2019) 'How Hindu nationalism went mainstream in Modi's India', Financial Times, 9 May, https://www.ft.com/content/4b68c89c-711c-11e9-bf5c-6eeb837566c5 [accessed 30.11.2020].

Kharas, H., McArthur, J. W. and Ohno, I. (eds.) (2019) Leave No One Behind. Time for Specifics on the Sustainable Development Goals, Washington, D.C.: Brookings Institution Press, https://www. brookings.edu/book/leave-no-one-behind/ [accessed 30.11.2020].

Kuchay, B. (2019) 'What you should know about India's "anti-Muslim" citizenship law', Aljazeera, 16 December, https://www.aljazeera.com/news/2019/12/india-anti-muslim-citizenship-bill-191209095557419.html [accessed 30.11.2020].

Laclau, E. (1994) 'Why do empty signifiers matter to politics?', in J. Weeks (ed.), The Lesser Evil and The Greater Good: The Theory and Politics of Social Diversity, London: Rivers Oram Press, 167-78.

Laclau, E. (1996) 'The death and resurrection of the theory of ideology', Journal of Political Ideologies 1, 3, 201-21.

Laclau, E. (2005) On Populist Reason, London: Verso.

Laclau, E. and Mouffe, C. (1987) Hegemony and Socialist Strategy: Towards a Radical Democratic Politics, London: Verso.

Malhotra, J. (2020) 'COVID fight: Modi's "no Indian left behind" mantra runs into "stay where you are" diplomacy', The Print, 24 March, https:/theprint.in/opinion/global-print/covid-fight-modi-indiannationals-left-mantra-stay-diplomacy/386750/ [accessed 30.11.2020].

Marschall, P. and Klingebiel, S. (2019) Populism: Consequences for Global Sustainable Development, Bonn: Deutsches Institut für Entwicklungspolitik (DIE), https://www.econstor.eu/bitstream/10419/ 199843/1/die-bp-2019-08.pdf [accessed 30.11.2020].

Munck, R. (2002) 'Global civil society: myths and prospects', Voluntas: International Journal of Voluntary and Nonprofit Organizations, 13, 4, 349-61

NITI Aayog (2017) On the Implementation of the Sustainable Development Goals: Voluntary National Report India, New Delhi: NITI Aayog, https://sustainabledevelopment.un.org/content/documents/ 15836India.pdf [accessed 30.11.2020].

NITI Aayog (2020) India VNR 2020: Decade of Action: Taking SDGs from Global to Local, New Delhi: NITI Aayog, https://sustainabledevelopment.un.org/content/documents/26281VNR_2020_India_Report. pdf [accessed 30.11.2020]. 
OECD (2018) 'Why leaving no one behind matters', in Development Co-operation Report 2018: Joining Forces to Leave No One Behind, Paris: OECD Publishing, https://www.oecd-ilibrary.org/docserver/ dcr-2018-7-en.pdf?expires=1587635442\&id=id\&accname=guest \& checksum=2FF812EF18B9E8FF53D7208DD5DC1B8E [accessed 30.11.2020].

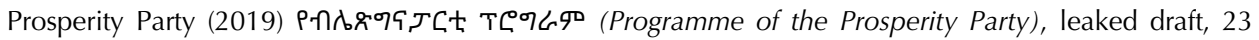
November, https://addisstandard.com/wp-content/uploads/2019/11/AS-Exclusive-Prosperity-PartyProgram-.pdf [accessed 08.05.2020].

Sachar, R. (2006) Social, Economic and Educational Status of the Muslim Community of India, A Report, New Delhi: Prime Minister's High Level Committee Cabinet Secretariat Government of India, http:// www.minorityaffairs.gov.in/sites/default/files/sachar_comm.pdf [accessed 30.11.2020].

Shariff, A. (2016) Institutionalizing Constitutional Rights: Post-Sachar Committee Scenario, New Delhi: Oxford University Press.

Staberock, G. and Christopoulos, D. (2019) The 2019 CSO Law: Winds of Change for Human Rights Defenders in Ethiopia? Geneva: OMCT, http://www.omct.org/files/2011/04/25315/omct_ethiopia_ briefing_web_version.pdf[accessed 30.11.2020].

Tomalin, E. (2013) Religions and Development, London and New York: Routledge.

Tomalin, E. (ed.) (2015) The Routledge Handbook of Religions and Global Development, London and New York: Routledge.

Tomalin, E. (2019) 'Faith and global aid: an "actor oriented" approach to the "turn to religion"', International Affairs, 96, 2, 323-42.

Tomalin, E., Haustein, J., and Kidy, S. (2017) Workshop Report: Citizenship, Marginalities and Development, New Delhi, 9 December, https://religions-and-development.leeds.ac.uk/wp-content/uploads/ sites/10/2017/06/Workshop-Report-India_FINAL_Agreed.pdf [accessed 30.11.2020].

Tomalin, E. and Haustein, J. (2020) 'Local faith communities and the Sustainable Development Goals in India and Ethiopia', in K. Kraft. and O. J. Wilkinson (eds.), International Development and Local Faith Actors: Ideological and Cultural Encounters, London: Routledge, 163-76.

Tomalin, E., Haustein, J. and Kidy, S. (2019) 'Religion and the Sustainable Development Goals', The Review of Faith and International Affairs 17, 2, 102-18.

Vaishnav, M. (2020) 'India's government is prioritizing nationalism over economic renewal', Washington Post, 30 January, https:/www.washingtonpost.com/opinions/2020/01/30/indias-government-isprioritizing-nationalism-over-economic-renewal/ [accessed 30.11.2020].

Woldegiorgis, G. (2009) 'Proclamation no. 621/2009: Proclamation to provide for the registration and regulation of charities and societies', Federal Negarit Gazeta 15, 25, 4521-67.

Woodyatt, A. and Pokharel, S. (2019) 'Indian parliament criminalizes Muslim practice of instant divorce', CNN World, 7 July, https://edition.cnn.com/2019/07/31/india/triple-talaq-criminalized-india-intl-scli/ index.html [accessed 30.11.2020].

Wraight, T. (2018) Populism and the 'Left Behind': towards a clearer conceptualisation', Aalborg: Danish Political Science Association, https://dpsa.dk/papers/Populism\%20and\%20the\%20Left\%20Behind. pdf [accessed 30.11.2020].

Zuquete, J. P. (2017) 'Religion and populism', in C. R. Kaltwasser, P. Taggart, P. O. Espejo, and P. Ostiguy (eds.), The Oxford Handbook of Populism, Oxford: Oxford University Press, 445-66. 